\title{
'Ambition and impatience' blamed for fraud
}

Washington. Fresh efforts to crack down on scientific misconduct could follow last week's revelations of extraordinary and systematic fraud by a graduate student in the laboratory of Francis Collins, director of the National Center for Human Genome Research (NCHGR) at the National Institutes of Health (NIH).

Collins was the senior author of five papers, each of which will be partially or wholly withdrawn in the wake of the fraud. His student is alleged to have fabricated data in studies of a genetic inversion that is believed to cause childhood leukaemia.

Speculating on why someone would do such a thing, Collins blames the impatient ambition of the gifted. The brightest students sometimes lack patience with the tedious business of conducting experiments properly, he says. Perhaps tellingly, Collins says the student's father was "a scientist of some renown".

$\mathrm{He}$ adds that the student, who accompanied Collins when he moved from the University of Michigan to take charge of NCHGR on the NIH campus in Bethesda was exceptionally bright, "probably the most impressive you'd come across in ten years". Collins also denies that the work was inadequately supervised. "This wasn't somebody working away in a corner. It was a student I was very involved with."

\section{Scientists 'too quick' to back claims}

Boston. David Baltimore, the Nobel laureate and professor of immunology at the Massachusetts Institute of Technology (MIT), last week criticized scientists who had been "much too quick" to support allegations of scientific misconduct against Theresa Imanishi-Kari, his co-author on a 1986 paper in the journal Cell.

Imanishi-Kari, a researcher at Tufts University in Medford, Massachusetts, was acquitted of the charges earlier this year (see Nature 381, 719; 1996). In his first public appearance to discuss the case, Baltimore complained about the behaviour of the "self-appointed fraud-busters" at the National Institutes of Health $(\mathrm{NIH})$, the bullying tactics of Congressman John Dingell and his staff, and what he called the error-ridden reporting of a "monolithic press".

Baltimore was speaking at a colloquium sponsored jointly by MIT's Science, Technology and Society programme and Harvard University's history of science department. He made various suggestions about an appropriate response to allegations of scientific fraud.

Such charges, he said, should be addressed in an even-handed manner. "If one approaches a case with a preconception that fraud has occurred, many steps in the scientific process which appear fraudulent merely reflect the personal and creative aspects of science." It is important to return to the presumption that fraud in basic research is rare because of the "near certainty" of it being detected, he added. "We do not need fraud police."

$\mathrm{He}$ admitted that both incidents and allegations of fraud occur occasionally, but rarely, and that the US federal government needs a mechanism to respond. "But such an investigation should not involve people who are interested in proving guilt or non-guilt, nor should an accuser be taken on as an adjunct to the [investigative] committee's activities," he said after the meeting.

Baltimore pointed out that universities have to be able to respond fast, with an inquiry board sufficiently separate from both the work and the parties involved to be able to operate independently. "You need to safeguard everybody, both the accused and the accuser, and an ombudsman can do that," he said.

MIT has adopted more rigorous protocols for dealing with academic misconduct since charges were first brought against Imanishi-Kari. The guidelines are designed to protect the privacy of both those who report apparent misconduct and the alleged offenders. They instruct supervisors to bring such situations promptly to the attention of the institute's senior officials.

"One area where MIT and Tufts failed [in handling the Imanishi-Kari case] was in having a clear, written record of the proceedings," Baltimore said. "That wasn't surprising since, at the time, noone had any conception that this would blow up in the way that it did." He now advises students to maintain detailed accounts of experiments so that "five or ten years from now, they'll be able to reconstruct everything that they did".

Journalists, Baltimore said, need to approach such cases with an open mind. "Reporters must look behind the situation and conduct their own investigation, and not just be the prisoners of leaks." One of the panellists at the colloquium, Malcolm Gladwell, who covered the case for the Washington Post, admitted that the press was "manipulated" and "pulled along in the creation of a controversy and sustaining of a controversy".

Steve Nadis
The fraud was uncovered when an anonymous reviewer of a sixth paper, submitted to the journal Oncogene, noticed that a figure appeared to have been falsified.

Collins said that he had considered resigning his post at NCHGR after the fraud was uncovered in August, but had been persuaded by friends not to do so. "This is the worst nightmare a scientist has, that the truth could be undermined right under your nose," he says. "I knew that some people might question if I could continue to play an effective role as head of the centre, but I was encouraged by people whose judgement I value not to draw that conclusion."

Collins was due to address the annual meeting of the American Society of Human Genetics at San Francisco when news of the fraud broke in the Chicago Tribune. $\mathrm{He}$ prefaced his lecture with an explanation of the case that appeared to win the support of those present, whom he referred to as "my family".

But Kenneth Ryan, a professor of obstetrics at Harvard University and chair of a national commission that has called for tighter regulation of government-funded science, said the case raised questions about what supervision the student was receiving.

"My heart goes out" to Collins, Ryan added. "It could happen to anybody. But this is science's problem, and scientists should get their heads together and take it seriously." The US government is currently considering changes in the definition and handling of misconduct in response to the Ryan commission's recommendations.

Under current rules for investigating scientific misconduct, the case should have been kept secret until an investigation was completed by the University of Michigan and passed to the Office of Research Integrity, which would determine sanctions and make a public announcement.

But, in a move designed to minimize scientific fall-out from the case, Collins wrote to 100 colleagues on 1 October, outlining the sequence of events and listing the papers to be retracted. The letter did not identify the student. But his identity could be readily inferred from the papers, and he was named in the New York Times last week as Amitov Hajra.

A lawyer for Hajra told the newspaper that he would have no comment until the University of Michigan had completed its investigation. A spokeswoman for the university says that will take "several weeks".

Hajra had been studying the core binding factor beta (CBFB) gene, which is believed to combine with another gene, smooth muscle myosin heavy chain (SMMHC), to form a fusion protein which divides and multiplies to cause leukaemia. He and Collins were the only authors of a paper published in Genomics $(26,571 ; 1995)$ on 
the structure of the CBFB gene, which is to be retracted in full.

Another 1995 paper in Molecular and Cellular Biology will also be fully retracted, while two more extensive studies published in the Proceedings of the National Academy of Sciences on the behaviour of CBFBSMMHC in vitro will be partially retracted, along with a fifth paper from the journal Genes, Chromosomes and Cancer.

When the problem with the figure in the sixth paper was brought to Collins' attention by the editors of Oncogene, it took him "about half an hour" to verify that it had been falsified, Collins says. There followed "two weeks of digging back" through laboratory records "collecting evidence that there had been systematic, long term fabrication" of results. The student admitted the fabrication, orally and in writing, Collins says.

Asked why he had not noticed the problem with the figure himself, Collins says

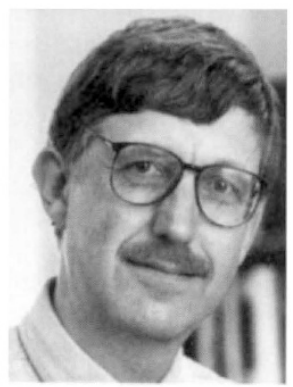

Collins: checking false figure took little time. he thinks that it is unusual for people to look at figures with a view to finding misrepresentation. "I may be doing more of that from now on," he says, adding that he is "intensely grateful" to the referce for noticing the problem.

As for the question of whether anyone can supervise a laboratory and run a large operation such as NCHGR at the same time, Collins says that he ran his lab there much the same way as he had done at the University of Michigan. Supervision of its work was "just too important to me" to neglect.

He said that it was "hard to know" how much time had been wasted by other scientists following the retracted work, but that "it wasn't a hot topic that everyone was jumping on".

But Ryan says that it is the loss of public trust, rather than the waste of research money, that scientists should be worrying about. He believes that fraud is much more widespread than the community admits.

Ryan wants a system of formal quality control, analogous to that used in industrial production,. introduced into federallyfunded laboratories. "I don't think enough is being done - and I've been beaten up pretty badly for saying so," says Ryan, referring to the community's hostile reaction to his commission's findings.

Even the severe critics of scientific conduct, however, congratulated Collins on his handling of this case once the fraud was detected. According to Walter Stewart, an outspoken critic of scientific misconduct who works at NIH, "on the facts as we know them now, the community owes him a great debt for doing the right thing in the most difficult of circumstances". Colin Macilwain

\section{British ruling supports legal challenge to broad patents}

London. Britain's House of Lords delivered its first legal judgement on genetic engineering patents last week, and gave a significant boost to the efforts of the European biotechnology industry to limit the breadth of protection that can be claimed for a single invention or discovery.

The move came as part of a decision by the Lords, which acts as Britain's highest legal authority, to uphold an appeal court decision invalidating a patent issued to Biogen Inc., based in Cambridge, Massachusetts, for a method of producing vaccines for hepatitis-B using genetically-engineered antigens.

The patent was based on research carried out by Kenneth Murray of the University of Edinburgh in the late 1970s. The immediate beneficiary of last week's decision is the British company Medeva, which plans to market its own hepatitis-B vaccine next year. Although this is based on a different genetic engineering technology, Medeva had been sued by Biogen for patent infringement.

But the decision has much broader implications, as it addresses what many in the biotechnology industry see as a major weakness in European patent legislation: the fact that, under the European Patent Convention, once a patent has been granted it cannot be challenged on the basis of the breadth of its claims.

Last year, the House of Commons select committee on science and technology, in its report on human genetics, recommended that the convention be "redrawn" to allow patents to be challenged on the grounds that their claims go too wide.

This proposal reflects a widespread view in the industry that, particularly in the early days of genetic engineering, several patents of questionable breadth were granted. One controversial example is the broad claim that has been granted to W. French Anderson and his colleagues in the United States for ex vivo techniques of gene therapy (see Nature 374, 393; 1995).

Attempts earlier this year by representatives of the biotechnology industry to persuade the European Patent Office, which is responsible for issuing Europe-wide patents under the convention, to change the rules on patent challenges were rebuffed.

But last week's ruling appears to move a substantial distance in this direction. Lord Hoffmann, the law Lord who wrote the ruling and is himself a former judge, appears to establish - at least under British law - that, even though the breadth of a patent claim is not explicitly listed as one of the aspects on which a patent can be challenged, questions of excessive breadth can nevertheless be used as the basis for mounting such a challenge.

Hoffmann emphasized in his ruling that care was needed "not to stifle further research and healthy competition by allowing the first person who had found a way of achieving an obviously desirable goal to monopolize every other way of doing it". And he added: "The Wright brothers had shown that heavier than air flight was possible, but that had not entitled them to a monopoly of heavier-than-air flying machines."

Gerald Kamstra, a patent attorney with the company Simmons and Simmons in London, says: "This decision goes some way to achieving what the industry has been seeking, at least in the United Kingdom."

Similarly, Nicholas Scott Ram, a senior executive with British Biotech and an adviser to the Bioindustry Association, the industry lobby group, welcomes what he calls "the right decision". Scott Ram adds: "It puts a handle on the question of the scope of a claim, and helps to ensure that the reward represented by a patent is commensurate with the work put into it."

The House of Lords' judgement effectively overturns an initial ruling by a patent judge that Medeva's technique for producing hepatitis-B antigens, although based on very different technology (including full knowledge of the genomic sequence of the virus, which was unknown at the time of Holmes' work), did indeed infringe the Biogen patent.

Medeva managed to have this ruling overturned by the Court of Appeal in 1994. The appeal court ruled that the patent was invalid both because the techniques that Murray had used to obtain hepatitis-B antigens using recombinant DNA technology were "obvious" at the time, and because the claims in the patent application, seeking the rights to all recombinant DNA molecules coding for hepatitis-B antigens, were too broad.

Biogen appealed against this ruling to the House of Lords, which upheld its claim that the techniques used by Murray were in fact novel enough to justify the patent. But the Lords also judged that the patent application had gone too far, and that as a result the patent was invalid.

A spokeswoman for Medeva - which acquired the rights to its own drug, currently in phase three clinical trials, from Swiss and German scientists in 1992 - welcomed what she described as a "decisive victory" for the company. Officials of Biogen said that the company was "clearly disappointed" by the decision, but would continue to collect royalties on British sales of its own vaccine.

David Dickson 